Article

\title{
Combustion Behaviors of CIGS Thin-Film Solar Modules from Cone Calorimeter Tests
}

\author{
Lulu Yin, Yong Jiang * and Rong Qiu \\ State Key Laboratory of Fire Science, University of Science and Technology of China, Hefei 230026, China; \\ ycode@mail.ustc.edu.cn (L.Y.); rqh@mail.ustc.edu.cn (R.Q.) \\ * Correspondence: yjjiang@ustc.edu.cn; Tel.: +86-551-6360-7827
}

Received: 23 June 2018; Accepted: 1 August 2018; Published: 4 August 2018

\begin{abstract}
As is well known, building integrated photovoltaic (BIPV) technology is becoming more commonly used in residential and commercial buildings. Fire assessment of photovoltaic (PV) modules as a whole is still insufficient. This work focuses on the thermal properties and combustion behavior of CIGS (copper, indium, gallium and selenium) thin-film modules. Cone calorimeter experiments were conducted at different external heat flux of 25, 30, 35, 40 and $45 \mathrm{~kW} \mathrm{~m}^{-2}$. Several parameters are discussed, including surface temperature, ignition time, heat release rate ( $\mathrm{HRR})$, mass loss rate, carbon monoxide $(\mathrm{CO})$ and carbon dioxide $\left(\mathrm{CO}_{2}\right)$ concentrations. The results show that CIGS thin-film solar modules are inflammable at intermediate or high flashover risk. A correction calculation for the gas toxicity index has been used to reduce the well-ventilation condition effect. Compared with the uncorrected calculation, peak fractional effective dose (FED) and lethal concentration for $50 \%$ of the population $\left(L C_{50}\right)$ are almost double. This work will help to determine a more stringent fire safety provision for PV modules.
\end{abstract}

Keywords: photovoltaic fires; CIGS; flammability; fire hazard; cone calorimeter

\section{Introduction}

\subsection{Background}

Solar cells have been used in building integrated photovoltaic (BIPV) systems, vehicles, aerospace applications and solar power plants. Photovoltaic (PV) technologies are divided into three generations, which are wafer-based (1st generation PV), thin-film cell (2nd generation PV) and new emerging technologies (3rd generation PV). However, the latter has not been used in the PV market recently [1]. The advantages of thin-film solar technologies are flexibility and minimum material usage for good cost effectiveness [2]. Furthermore, the conservation of energy, materials and thin-film processes are eco-friendly.

As for PV device design and fabrication, there are choices to be made in areas such as substrates (flexible or grid, metal or insulator), layers (e.g., contact, buffer, absorber reflector, etc.) and techniques (e.g., PVD, CVD, ECD, plasma-based, hybrid, etc.) [3]. The most widely commercialized thin-film solar cells include a-Si (thin-film amorphous silicon), CdTe (compound semiconductor cadmium telluride) and compound semiconductor made of CIGS (copper, indium, gallium and selenium). CIGS solar cell is presently regarded as the highest light-to-power conversion efficiency material [2,4]. The best efficiency of CIGS is $22.3 \%$ [5], compared with CdTe (22.1\%) [6] and $\alpha$-Si (13.6\%) [7].

New techniques such as nanotechnology improve solar cell application efficiency. Adding reduced erbium-doped ceria nanoparticles as a coating on silicon solar cells can improve efficiency from $15 \%$ to 16.5\% [8]. For CIGS cells, random distribution of $\mathrm{Au}$ and $\mathrm{Ag}$ nanoparticles broadens the resonance wavelength of the transmittance, and improves efficiency by $1.2 \%$ and $1.4 \%$ [9]. Hyper branched nanostructures also increase efficiency. When it used in FTO-glass sensitized with D-102 dye, 
a maximum efficiency of $3.96 \%$ is reached [10]. Al-doped $\mathrm{ZnO}$ nanostructured films as transparent electrodes in photovoltaic devices shows high Haze factor ( $>80 \%)$ and may be exploited to enhance the light trapping capability [11]. Metallic nanowires could boost the conductivity of the front conductor, while the optical penalty can be solved by introducing a texture [12]. Thin-film techniques make solar modules become a promising approach for terrestrial and space applications. Thin-film modules are a suitable choice for new building types, for instance ETFE (ethylene tetrafluoroethylene) cushion structure. ETFE structure is often used in stadiums and airport terminals, like the National Aquatics Center for the 2008 Olympic Games. Temperature distribution and characteristics of a two-layer ETFE cushion integrated flexible PV also had been studied in Hu's research [8].

These technologies ensure CIGS thin-film solar modules' mass production and prospects for extensive use. Modules used in our test are CIGS thin-film PV with a cover layer of ETFE. This module can be integrated on curved surfaces due to its flexible substrate. Samples used in our research are made of transparent contact-layer, blue cell, green cell, red cell, reflecting metal-layer and flexible substrate [13]. Compared with Si PV, they have light-spectrum-splitting capacity to reach higher efficiency [14].

\subsection{Fire Hazard}

PV system fires are common in residential and commercial properties. PV systems are often accompanied by high life-threatening voltages, from 300 to 1000 Volts DC [15], and have the potential risk of spontaneous ignition. When a fire occurs, it is hard to cut off the electric circuit to make sure all components are de-energized. The light-to-power systems work under light irradiation as long as they are not totally destroyed. For firefighters, it is much more difficult to deal with the potential high voltage, since it puts their lives in danger. At present, PV module research has mainly focused on fire-resistance testing and fire preventing. There are several standards for PV module fire safety tests, such as IEC 61730-2 [16], UL 1703 [17] or even UL 1256 [18]. New research still improves these standards. For example, a modified IEC 61730-2 [16] by Wohlgemuth et al. [15] includes overheat caused by hot spots, high series resistance or arcing.

It is worth doing research about the burning behaviors and fire risks of solar modules. Guerin confirmed the risk of fire with the large-scale solar photovoltaic construction project in Reference [19]. Based on the perspective of firefighters, Casey focused on firefighting of solar photovoltaic panels. Casey also suggested a practice guidance for firefighters for emergency response [20]. Guerin and Casey notice that the performance of rooftop solar panels under radiant heat is unknown. Besides this, computational fluid dynamics (CFD) fire modeling tools also need effective material properties, especially for large-scale simulation. Thermal degradation of solid fuels in a fire situation is complex, because of interactions between different materials. Taking PV modules as a whole is a direct way to reduce the amount of computation required.

However, fire hazard research concerned with taking PV modules as a whole is still insufficient. In order to investigate the emissions and redistribution of elements, a commercial CdTe PV module was heated up to $1273 \mathrm{~K}$ to simulate exposure to fires [21]. Yang et al. focused on the flammability and fire hazards of polycrystalline silicon PV modules with glass covering [22]. In their research, a whole silicon PV module was ignited under external radiation during cone calorimeter tests. Both heat and smoke were discussed, because those are necessary when assessing full-scale fire. Cone calorimeter is a widely used device to measure fire reaction properties, in fire potential assessment of wood, polymer, and even for batteries. Fu's paper concerning cone calorimeter tests of lithium ion batteries indicates that the collected data can be used directly, as well as input data for mathematical models to analyze the thermal and chemical threats [23].

Our research focuses on the combustion behaviors and thermal hazards of CIGS thin-film solar modules. We also discuss the difference of fire behaviors, compared to Yang's results for rigid polycrystalline silicon PV modules. Compared with rigid solar modules, flexible modules use polymer as the top layer and flex backsheet as bottom layer. Additionally, encapsulant layers bring more combustible. In order to evaluate the effects of irradiation on properties and discuss the thermal 
properties and gas toxicity, these parameters are measured: surface temperature, ignition time, heat release rate, mass loss rate, $\mathrm{CO}$ concentration and $\mathrm{CO}_{2}$ concentration. An evaluation system proposed by Petrella has been introduced to classify the danger of heat contribution and flashover quantitatively. Well-ventilation cone calorimeter test condition causes an underestimate of toxic gas concentration. This underestimate could be dangerous when assessing building fire safety level and arranging for evacuation. Han and Chow provide a correction calculation for the gas toxicity index in cone calorimeter test [24]. In our work, we adopt these two evaluation systems and compare the results of Petrella's and Han and Chow's.

\section{Experimental Setup}

\subsection{Samples}

In this experiment, samples were collected from MiaSolé FLEX-01 70N [25]. FLEX-01 70N is a manufactured product with a scale of $1723 \mathrm{~mm} \times 370 \mathrm{~mm} \times 2.5 \mathrm{~mm}$ (thickness with adhesive), shown in Figure 1a. This batch production can be separated into three parts: sensitive part, back adhesive and periphery. The sensitive part is the section with CIGS solar cells, which is the functional area that transforms light energy to electrical energy. Figure $1 \mathrm{~b}$ shows the sensitive part as a specimen in sample holder. Figure 1c shows a slice of packaged CIGS solar cell, with the sensitive part having a width of $5 \mathrm{~cm}$. Back adhesive helps the module to remain fixed and does not have a light to electric transformative function, shown in Figure 1d. There are three adhesive slices, with a width of $10.3 \mathrm{~cm}$ each. On the periphery is the outer edge of the sensitive part, with the function of protection and electric circuit. As shown in Figure 1, the black outer ring (with a width of $2.2 \mathrm{~cm}$ ) around the module is the periphery to protect the sensitive parts. Only the sensitive part was taken into consideration, without back adhesives and periphery. Samples were of the size $100 \mathrm{~mm} \times 100 \mathrm{~mm} \times 1.5 \mathrm{~mm}$ with a weight of $29 \pm 2 \mathrm{~g}$. All samples were wrapped using the shiny side of an aluminum foil layer. Then samples were put in a holder frame with an open window area of $84 \mathrm{~mm} \times 84 \mathrm{~mm}$. The sample can be separated into the four layers of ETFE, solar cells, metal backboard, and polyethylene terephthalate (PET), from top to bottom.

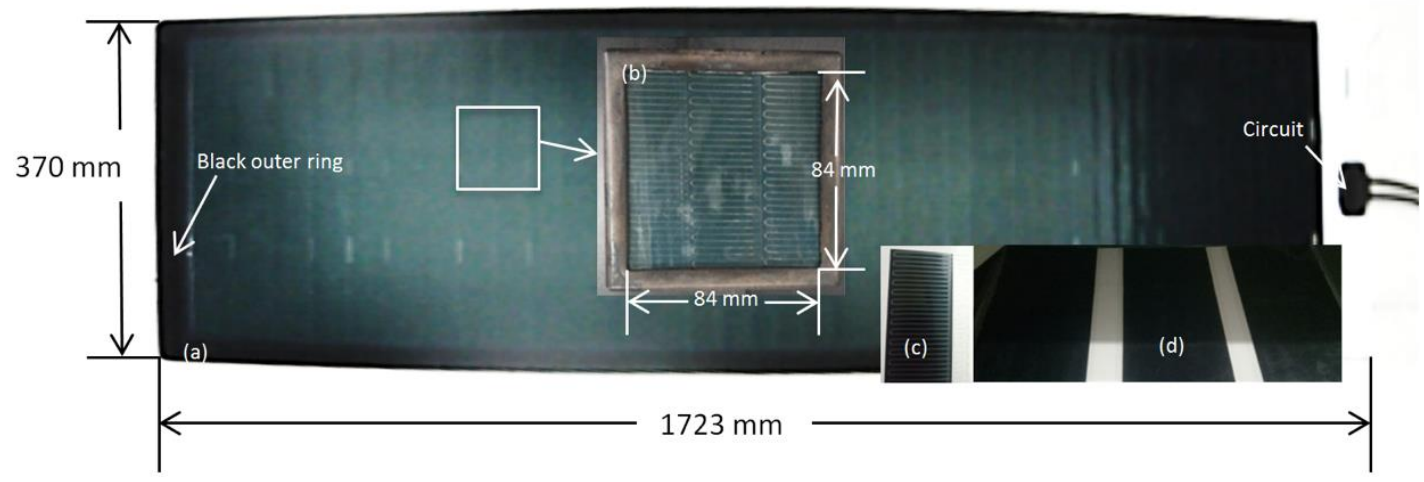

Figure 1. Copper, indium, gallium and selenium (CIGS) thin-film solar module and sample. (a) module;

(b) specimen; (c) CIGS solar cell sample; (d) adhesive.

\subsection{Apparatus}

Experiment procedures were conducted according to the ISO 5660 standard [26] with a cone calorimeter developed by Fire Testing Technology under well-ventilated conditions. The schematic of a cone calorimeter is shown in Figure 2 [27]. Forced-flaming combustion by external radiation was chosen to investigate flame. Tests were conducted at various levels of heat flux ranging from 20 to $45 \mathrm{~kW} \mathrm{~m}^{-2}$. In order to reach real fire heat flux level, external radiation was employed. Babrauskas suggests that $25-50 \mathrm{~kW} \mathrm{~m}^{-2}$ is suitable for most research purposes [28]. In this research, $45 \mathrm{~kW} \mathrm{~m}^{-2}$ 
was enough to reach a short enough ignition time. The experiments were stopped manually according to the mass loss rate criterion. That means the test ends when the average mass loss rate drops lower than $1 \mathrm{~g} \mathrm{~m}^{-2}$ in a $60 \mathrm{~s}$ period. Two K-type thermocouples were used in the thermally thick tests to get the temperature of upper and lower surfaces. For each condition, tests were repeated at least twice to ensure reproducibility. These parameters were measured: surface temperature, ignition time, heat release rate, mass loss rate, $\mathrm{CO}$ concentration and $\mathrm{CO}_{2}$ concentration.

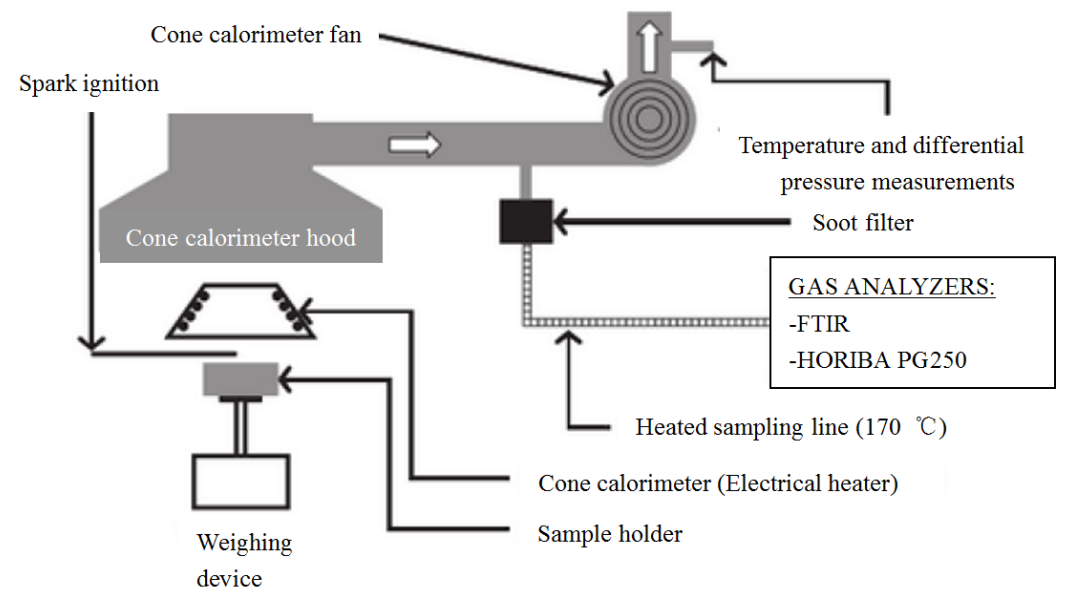

Figure 2. Schematic of a cone calorimeter [27].

\section{Results}

\subsection{Burning Behavior}

Figure 3 presents the screenshots from a combustion test video shot using a Canon digital video camera. It presents a burning progress with the four typical stages of heating, ignition, rapid burning and extinction. After being exposed to external heat flux for a while, vapors rise above the sample surface. Then vapors increases in quantity. The front ETFE cover melts with blistering, shown in Figure 3a. With high external radiation, the blistering is more intense. Then ignition appears from the higher part of the steam, shown in Figure 3b. Flammable steam is lit, and the combustion begins. This time interval from exposed to external radiation to the ignition is usually called ignition time $\left(t_{i g}\right)$. With higher external radiation, ignition comes earlier. The flames become larger rapidly with a cluster of bubbles, shown in Figure 3c. The fire reaches its maximum and then becomes smaller gradually. With the fuel running out, the flames extinguish, shown in Figure 3d. After the test, solid residue can be found in the sample holder, such as burning ash, CIGS cells, metal etc. During the heating period, shape changes of the three CIGS chips happened, while they used to be arranged in parallel. These shape changes lead to lower-layer combustible melts exposure to the fire, air and external heat flux. In this experiment, the sample holder can be considered as a limited space without combustible melts spreading out. In a real fire, these melts can exacerbate the risk of a fire spreading.

Figure 4 shows the SEM images of CIGS cell layer. The device used is a GeminiSEM 500, Carl Zeiss, Germany. Figure $4 \mathrm{a}, \mathrm{b}$ shows the top surface before and after burning test under external heat flux of $40 \mathrm{~kW} \mathrm{~m}^{-2}$. Before the test, uniform size particles can be found on the surface. After the test, the surface becomes irregular. Figure $4 \mathrm{c}$ shows the cross section image after test. A typical structure of CIGS thin-film solar cell can be separated into five layers: transparent conductive layers (TCL), CdS window, CIGS absorber, metal contact and substrate, from top to bottom [29]. These five layers can be found in Figure 4c. TCL are usually thin conductive metal oxides. MiaSole used $\mathrm{ZnO}$ for their front contact and Mo for their back contact [30]. Figure $4 \mathrm{~d}$ shows the details. It shows that surface particles do not melt or disappear. Some attachments appear on the surface and cover the TCL contact. Attachments may be the burning residue of ETFE. 

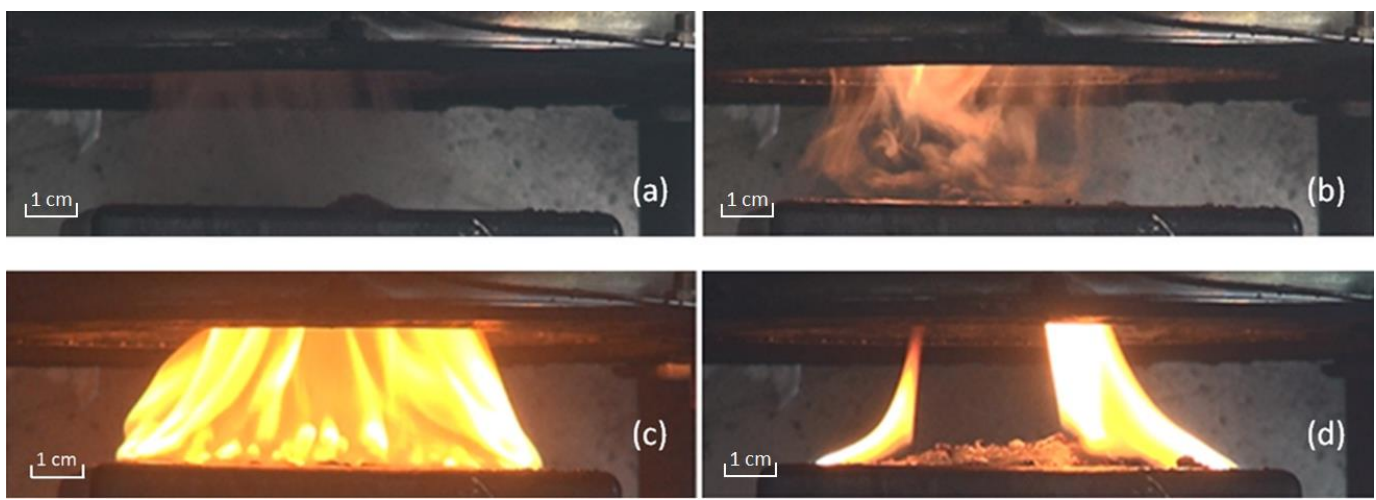

Figure 3. Burning process of CIGS specimen. (a) incipient stage; (b) ignition; (c) fully burning stage; (d) extinction stage.
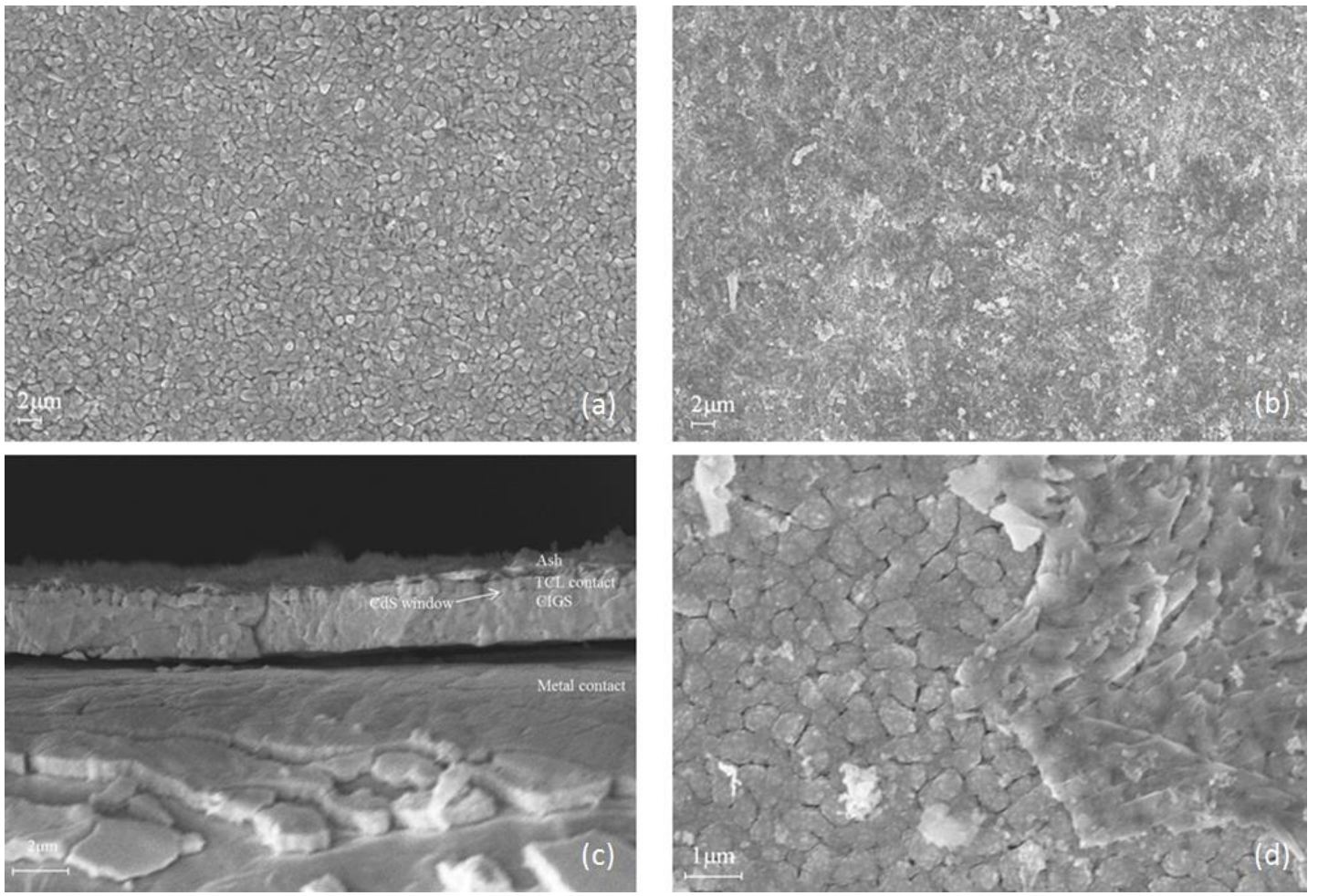

Figure 4. SEM images of CIGS cell layer. (a) top surface image before burning; (b) top surface image after burning; (c) cross section image after burning; (d) details of ash attachment.

\subsection{Thermally Thick}

Determining the CIGS module sample as thermally thin or thick is the premise to the parameters of ignitability and combustibility. Biot number (Bi) is calculated to classify whether material is thermally thick or thin [31], and can be expressed as:

$$
B i=\frac{h L}{k}
$$

where $h$ is heat transfer coefficient, $L$ is characteristic thickness, and $k$ is thermal conductivity of the solid, respectively. However, for a multi-material sample, it is hard to use this equation. An experimental method is presented below. With a thermally thick solid, the gradient of temperature 
in the solid sample can be observed [32]. Because of this feature, a temperature difference test was performed as follows, also used in Reference [33].

Thermocouples were placed at the upper and lower surfaces of the specimen to monitor the temperature difference, shown in Figure 5. The specimen was exposed to heat flux of $20 \mathrm{~kW} \mathrm{~m}^{-2}$. In the pre-test, specimens could not ignite at less than $20 \mathrm{~kW} \mathrm{~m}^{-2}$. This value is suitable for the temperature tests, because flame interference is eliminated. Temperature conducted by the thermocouple is shown in Figure 6. Temperature difference can be observed between two thermocouples during the whole test. The peak temperature difference is $122 \mathrm{~K}$. Temperature difference indicates that heat conduction inside the sample is much slower than heat convection away from its surface. Thus, the sample is thermally thick.

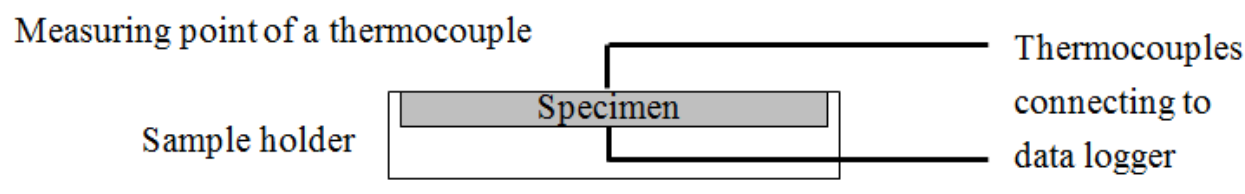

Figure 5. The schematic of setting up thermocouples.

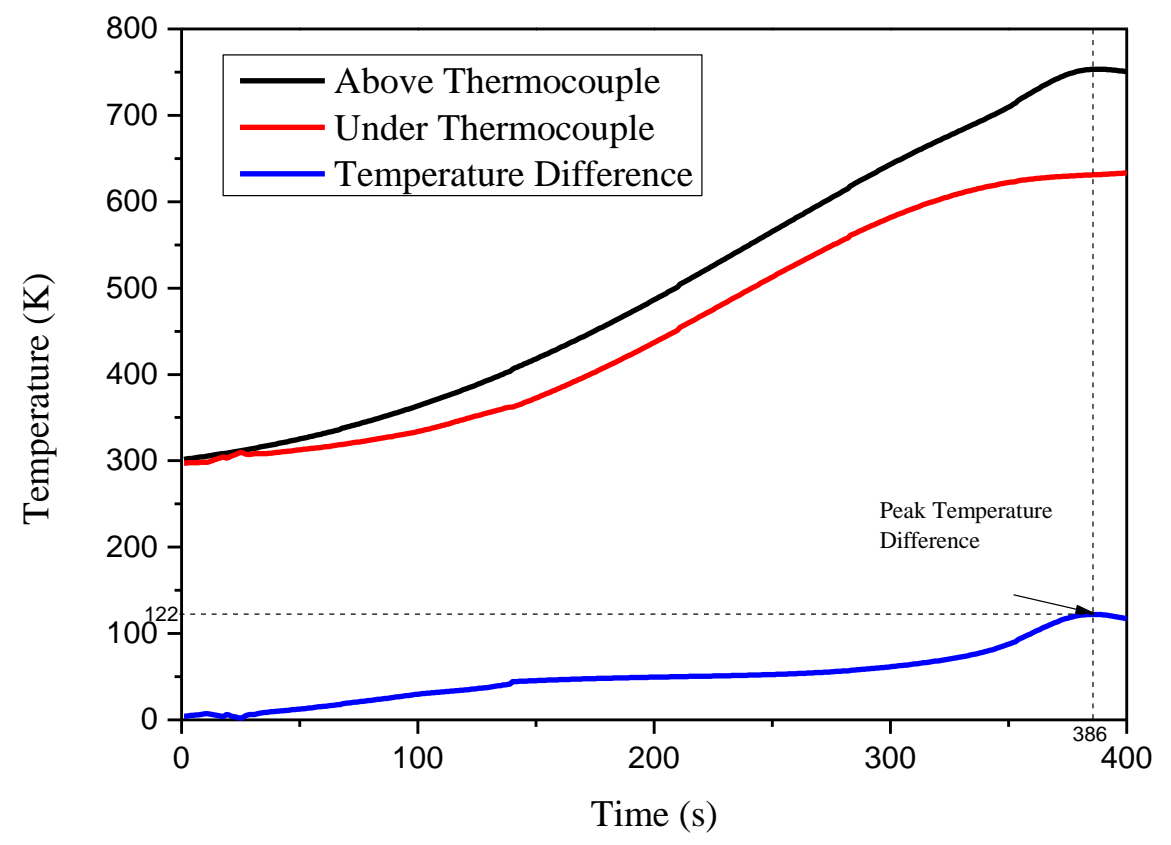

Figure 6. Temperature-time curves for two thermocouples at $20 \mathrm{~kW} \mathrm{~m}^{-2}$.

\subsection{Ignition Time}

Ignition time is a key parameter for fire resistance, and is an indicator of fire starting. Higher ignition time indicates longer time to heat up to ignition. The ignition time can be determined by the time interval from the initial exposure to irradiation $(t=0)$ to the moment a flame arises on the material surface.

A rapid decrease in ignition time is caused by the increase in heat flux. For example, $t_{i g}$ decreases from $128 \mathrm{~s}$ to $38 \mathrm{~s}$ when the heat flux increases from 25 to $45 \mathrm{~kW} \mathrm{~m}{ }^{-2}$. Several simplified heat conduction models have been developed for further analysis [34-36]. The model used in this work is proved by Quintiere [37]. Sample ignition can be achieved when an external heat flux $\left(\dot{q}_{e}^{\prime \prime}\right)$ is higher than a critical heat flux (CHF). During a time interval $\left(t_{i g}\right)$, the specimen ignites. For thermally thick materials, the ignition time is calculated by Equation (2):

$$
t_{i g}=\frac{\pi}{4} k \rho C_{p}\left(\frac{T_{i g}-T_{0}}{\dot{q}_{e}^{\prime \prime}}\right)^{2}
$$


where $\rho$ is density, $C_{p}$ is ignition constant, $T_{i g}$ is ignition temperature, $T_{0}$ is initial temperature, and $\dot{q}_{e}^{\prime \prime}$ is external heat flux. This equation is for thermally thick materials, also used in References [33,35-37]. In this model, the thermal response parameter (TRP) also has been computed, as Equation (3):

$$
\sqrt{\frac{1}{t_{i g}}}=\frac{\sqrt{4 / \pi\left(q_{e}^{\prime \prime}-C H F\right)}}{T R P}
$$

According to Equations (2) and (3):

$$
\begin{gathered}
C H F=-\frac{T R P \cdot y_{\text {intercept }}}{\sqrt{4 / \pi}} \\
T R P=\sqrt{\frac{4}{\pi}} \frac{1}{\text { Slope }}
\end{gathered}
$$

According to Equation (3), the square root of the inverse of time of ignition is a linear correlation with irradiation, shown in Figure 6. The linear trend shows that the specimen is thermally thick. This result is consistent with the previous thermocouples test results in Section 3.2. The straight line fits the data with the slope $=0.00364$ and the $y_{\text {intercept }}=-0.00329$. By applying Equations (4) and (5) to the last results from Figure 7, we get CHF $=0.90385 \mathrm{~kW} \mathrm{~m}^{-2}$ and TRP $=309.9943 \mathrm{~kW} \mathrm{~s}^{1 / 2} \mathrm{~m}^{-2}$. Then we get the theoretical CHF. According to the physical meaning of CHF, ignition occurs when external heat flux is larger than CHF. It is noteworthy that no naked fire can be observed during $1000 \mathrm{~s}$ under external heat flux at $20 \mathrm{~kW} \mathrm{~m}^{-2}$. The CHF of ETFE in communications cable insulation and jackets is $22 \mathrm{~kW} \mathrm{~m}^{-2}$ [38]. Using the theoretical CHF brings an underestimation of the module's retardant performance. The differences between experimental and extrapolated CHF are due to the following three reasons. Non-linearity of the ignition time leads to the non-linearity of the square root of the inverse of the ignition time for the lowest external heat flux, especially near the CHF [39]. Second, as a multi-layer sample, the cover layer also brings non-linearity [40]. Third, Delichatsios et al. [41] suggest that surface reradiation causes a higher critical heat flux than the extrapolated value.

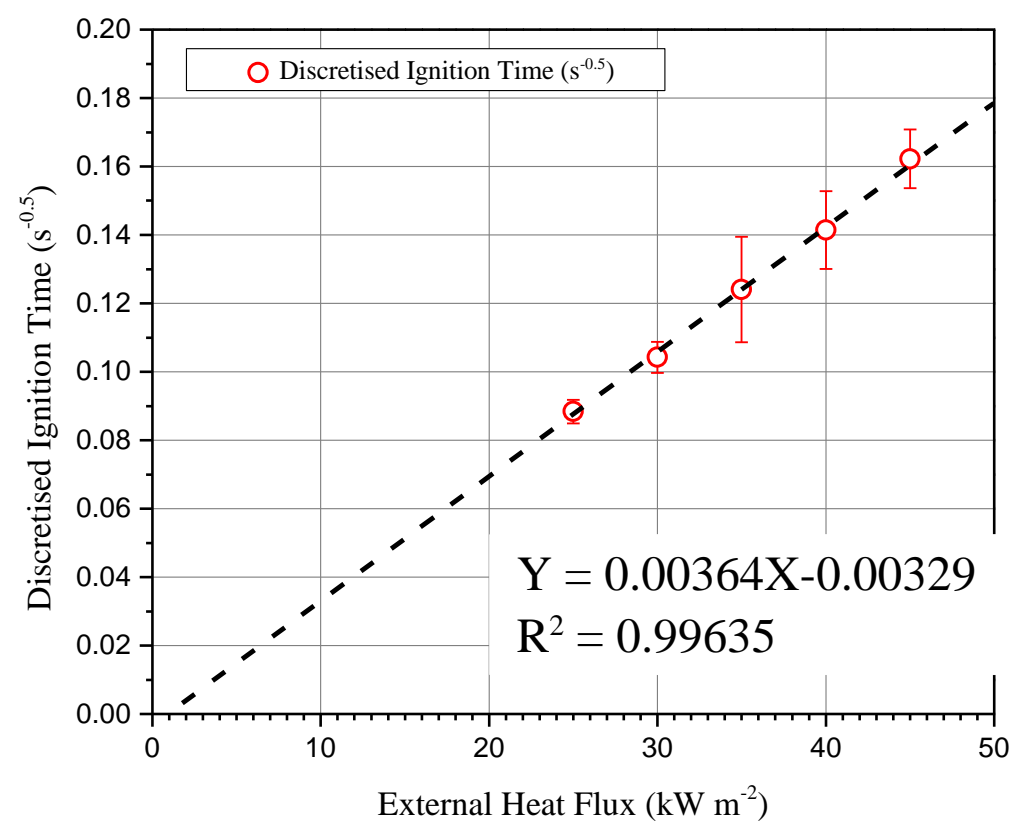

Figure 7. Square root of the inverse of ignition time $\left(\mathrm{s}^{-0.5}\right)$ as a function of radiant heat flux $\left(\mathrm{kW} \mathrm{m}^{-2}\right)$. 


\subsection{Heat Release Rate}

Heat release rate (HRR) is the rate at which fire releases energy, as discussed in many papers. HRR is considered to be the most important factor in controlling fire hazards, owing to its strong connections with several fire reaction properties [23]. It determines whether a neighbor module can be ignited when fire happens in a large solar power installation [42]. HRR also provides a correspondance between fire intensity and fire spread [43].

After a short time interval, HRR reaches its maximum, as peak HRR (pkHRR), and then it drops down to almost zero, as shown in Figure 8. When the heat flux increases from $25 \mathrm{~kW} \mathrm{~m}^{-2}$ to $45 \mathrm{~kW} \mathrm{~m}^{-2}$, the pkHRR changes from $475 \mathrm{~kW} \mathrm{~m}^{-2}$ to $1024 \mathrm{~kW} \mathrm{~m}^{-2}$. Furthermore, the time to reach pkHRR declines from $203 \mathrm{~s}$ to $90 \mathrm{~s}$.

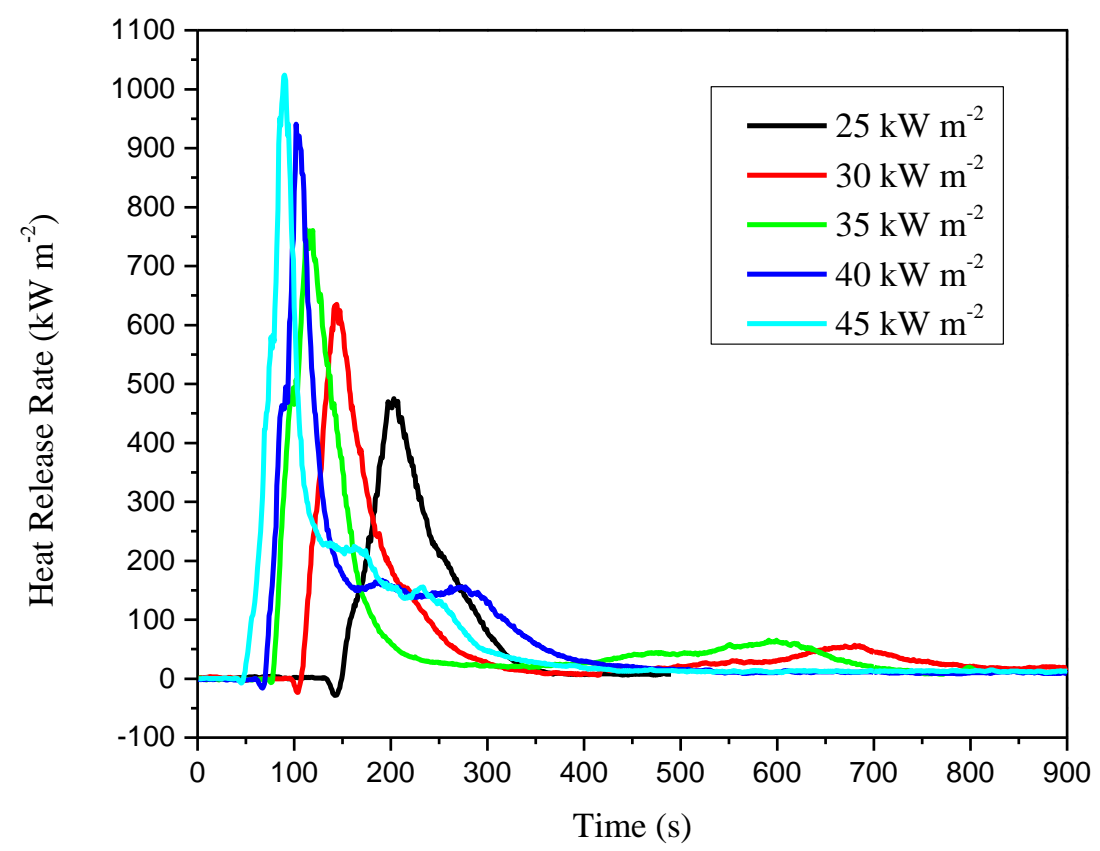

Figure 8. Heat release rate $\left(\mathrm{KW} \mathrm{m}^{-2}\right)$ versus time (s).

In order to analyze the risks of heat contribution and flashover, Petrella's evaluation system [43] is used, as with References [22,44]. In this system, two important parameters are proposed, called total heat release (THR) and $x$ parameter. THR is the time integration of HRR, indicating the fire thermal hazards of the material, and is calculated using Equation (5):

$$
T H R=\int H R R
$$

Additionally, the $x$ parameter is calculated using Equation (3), as a fraction of the heat release rate peak (pkHRR) to ignition time $\left(t_{i g}\right)$ :

$$
\mathrm{x}=\frac{p k H R R}{t_{i g}}
$$

Table 1 shows the details of Petrella's evaluation system. 
Table 1. Petrella's evaluation system.

\begin{tabular}{ccc}
\hline Values & Total Heat Release (THR) & $x$ Parameter \\
\hline $0.1-1.0$ & Very low risk to heat contribution & Low risk to flashover \\
$1.0-10$ & Low risk to heat contribution & Intermediate risk to flashover \\
$10-100$ & Intermediate low risk to heat contribution & High risk to flashover \\
$100-1000$ & High risk to heat contribution & - \\
\hline
\end{tabular}

From the experimental results shown in Table 2, and through comparison with Perella's value, we arrive at the following conclusions:

(1) In the experimental range of external heat flux under $45 \mathrm{~kW} \mathrm{~m}^{-2}$, the CIGS thin-film solar cells have intermediate low risk to heat contribution.

(2) The flashover risk is intermediate when the external heat flux is 25 and $30 \mathrm{~kW} \mathrm{~m}^{-2}$.

(3) When external heat flux becomes more than $35 \mathrm{~kW} \mathrm{~m}^{-2}$, the risk to flashover turns to high, which is much more dangerous than polycrystalline silicon modules, according to Yang's study [22].

(4) For a CIGS module used in the research with the power of $70 \mathrm{~W}$, it releases energy of $49.49 \mathrm{MJ}$ with the surface area of $0.638 \mathrm{~m}^{2}$ with external heat flux of $45 \mathrm{~kW} \mathrm{~m}{ }^{-2}$. Furthermore, BIPV systems always need multiple slices to form a panel, and even more for an array. Large-scale usage of this module, especially on the roof or wall of high-rise buildings, brings heavy fire load.

Table 2. Test results and thermal hazard classification.

\begin{tabular}{|c|c|c|c|c|}
\hline $\begin{array}{l}\text { External Heat Flux } \\
\quad\left(\mathrm{kW} \mathrm{m}^{-2}\right)\end{array}$ & $\begin{array}{c}\text { Peak Time } \\
\text { (s) }\end{array}$ & $\begin{array}{c}\text { pkHRR } \\
\left(\mathbf{k W ~ m ^ { - 2 }}\right)\end{array}$ & $\begin{array}{c}\text { THR } \\
\left(\mathrm{MJ} \mathrm{m}^{-2}\right)\end{array}$ & 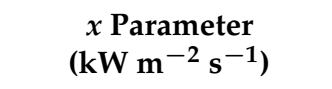 \\
\hline 25 & 203 & 475 & 38.95 (Intermediate risk) & 3.71 (Intermediate risk) \\
\hline 30 & 144 & 635 & 59.74 (Intermediate risk) & 6.90 (Intermediate risk) \\
\hline 35 & 112 & 762 & 62.5 (Intermediate risk) & 11.72 (High risk) \\
\hline 40 & 102 & 941 & 73.71 (Intermediate risk) & 18.82 (High risk) \\
\hline 45 & 90 & 1024 & 77.72 (Intermediate risk) & 26.95 (High risk) \\
\hline
\end{tabular}

\subsection{Mass Loss Rate}

The index to measure the level of pyrolysis, volatilization, and burning of the specimen during the whole cone calorimeter test under constant external heat flux is usually called mass loss rate (MLR). To calculate MLR, we chose five-point numerical differentiation equations. MLR is connected with heat release rate, specific extinction area, and CO yield [45], as shown in Figure 9. Mass loss rate curves reach their maximum values quickly with the increases of external heat flux, as the peak value at $25 \mathrm{~kW} \mathrm{~m}^{-2}$ is $0.225 \mathrm{~g} \mathrm{~s}^{-1}$.

Figure 8 shows the mass loss evolution and rate under different external heat flux. Data recorded during the experiment is shown, while time $t=0$ means the moment of the exposure to the desired irradiance. The end time is after the extinguishment.

Regardless of different external heat flux, two stages of thermal degradation can be observed. The MLR curve shapes depend on the irradiance level value weakly, but the peak values are strongly related to radiation intensity. When external heat flux increases from 25 to $45 \mathrm{~kW} \mathrm{~m}^{-2}$, the time to reach the maximum becomes shorter. For example, this time interval shortens from $185 \mathrm{~s}$ at $25 \mathrm{~kW}$ $\mathrm{m}^{-2}$ to $68 \mathrm{~s}$ at $45 \mathrm{~kW} \mathrm{~m}^{-2}$. Additionally, a higher maximal intensity of the MLR peak is reached. It increases from $0.141 \mathrm{~g} \mathrm{~s}^{-1}$ at $25 \mathrm{~kW} \mathrm{~m}^{-2}$ to $0.225 \mathrm{~g} \mathrm{~s}^{-1}$ at $45 \mathrm{~kW} \mathrm{~m}^{-2}$. After a period of time exposed to heat flux, the sample ignites and MLR quickly rises. Then MLR reaches its peak value, then decreases. During the whole decomposition process under each radiation, only one MLR peak is observed. That means the composites keep their thermally thick properties. 
The specific mass loss rate (SMLR) is determined as a ratio between MLR and the exposed sample surface in the cone calorimeter. Moreover, SMLR can be calculated with Equations (8) and (9):

$$
\begin{gathered}
S M L R=\left(\frac{1}{\Delta H_{g}}\right) \dot{q}_{e}^{\prime \prime}+\frac{F H F-\varepsilon \sigma T_{i g}^{4}}{\Delta H_{g}} \\
F H F_{n e t}=F H F-\varepsilon \sigma T_{i g}^{4}
\end{gathered}
$$

where $\varepsilon \sigma T_{i g}^{4}$ radiative heat flux loss and $\Delta H_{g}$ is latent heat of gasification. $\mathrm{FHF}_{\text {net }}$ means the heat flux which the specimen contributes, as a minus of the flame heat flux sum and radiative heat flux loss from the sample surface $[46,47]$.

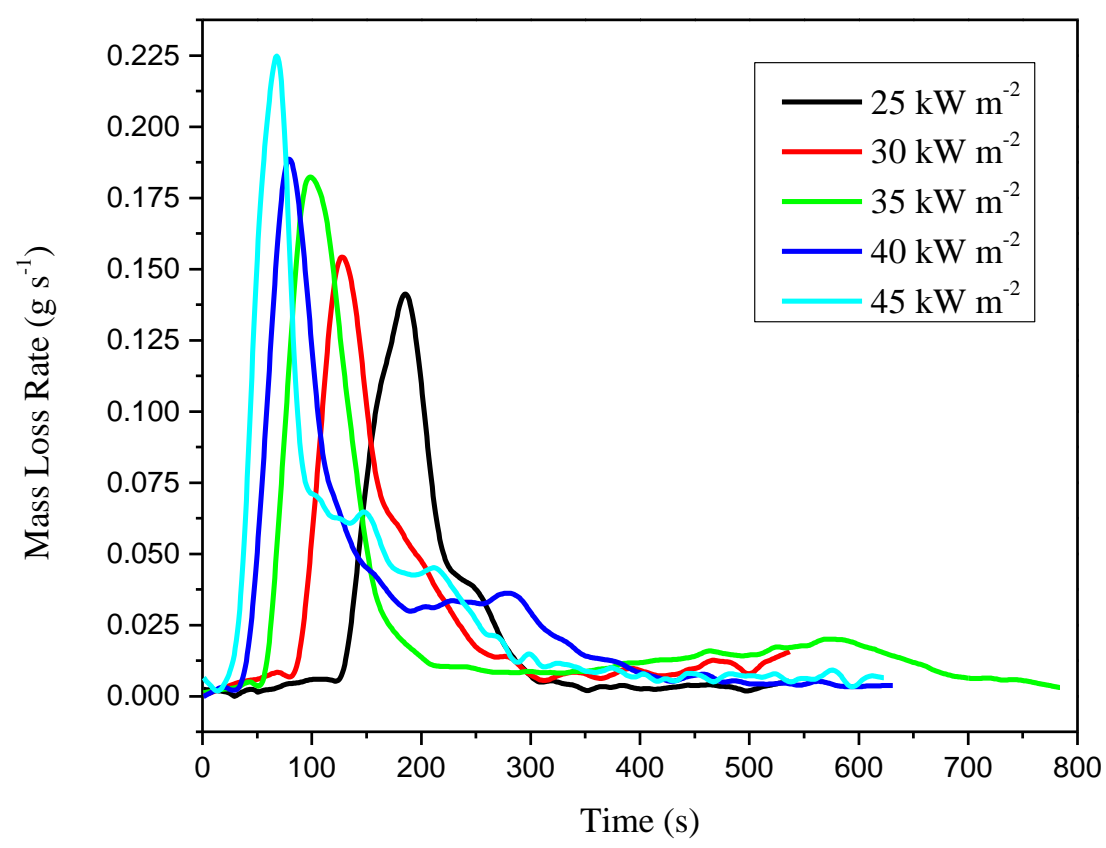

Figure 9. Mass loss rate $\left(\mathrm{g} \mathrm{s}^{-1}\right)$ as a function of experimental time(s).

Figure 10 shows the average SMLRs increase quickly with the rise of the external heat flux. The average SMLR increases from 2.35 to $3.92 \mathrm{~g} \mathrm{~m}^{-2} \mathrm{~s}^{-1}$ when incident heat flux increase from 25 to $45 \mathrm{~kW} \mathrm{~m}^{-2}$. The linear trend of average SMLR curve shows that the heat of gasification changes little when the module is considered as a whole. According to Equation (8), the slope $(=0.08)$ and $y_{\text {intercept }}(=0.39)$ of the best fit line of average SMLR vs. $\dot{q}_{e}^{\prime \prime}$ allow the computation of other thermal properties as Equation (10), such as gasification heat $\left(\Delta H_{g}=12.52 \mathrm{~kJ} \mathrm{~g}^{-1}\right)$, and net flame heat flux $\left(\mathrm{FHF}_{\text {net }}=4.91 \mathrm{~kW} \mathrm{~m}{ }^{-2}\right)$. These two parameters are required in fire modeling. The gasification heat is also used to estimate the fire resistance of a material [32].

$$
\text { Slope }=\frac{1}{\Delta H_{g}} ; y_{\text {intercept }}=\frac{F H F-\varepsilon \sigma T_{i g}^{4}}{\Delta H_{g}}
$$



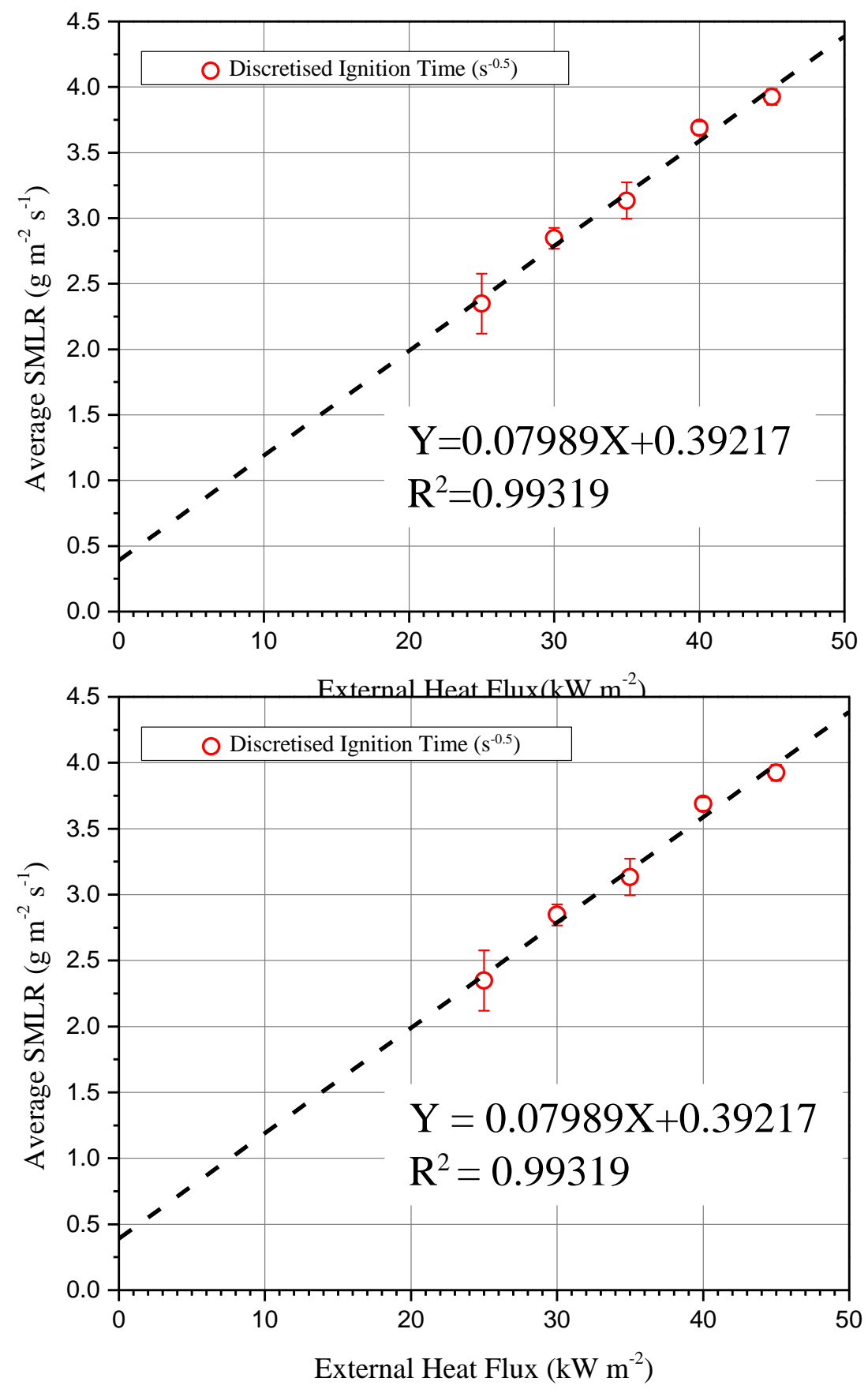

Figure 10. Averaged specific mass loss rate $\left(\mathrm{g} \mathrm{m}^{-2} \mathrm{~s}^{-1}\right)$ as a function of heat flux $\left(\mathrm{kW} \mathrm{m}^{-2}\right)$.

\subsection{Gas Toxicity}

Smoke inhalation accounts for roughly three quarters of all fire deaths. The concentrations of $\mathrm{CO}$ and $\mathrm{CO}_{2}$ detected by the cone calorimeter are shown in Figures 11 and 12 . The $\mathrm{CO}_{2}$ and $\mathrm{CO}$ yields for lower external heat flux are lower than that for higher external heat flux. In particular, in the test of external heat flux at $45 \mathrm{~kW} \mathrm{~m}^{-2}$, the concentration of $\mathrm{CO}$ increased significantly after the ignition, and the concentration reached its maximum of $411.5 \mathrm{ppm}$ with an aiguille on the curve. 


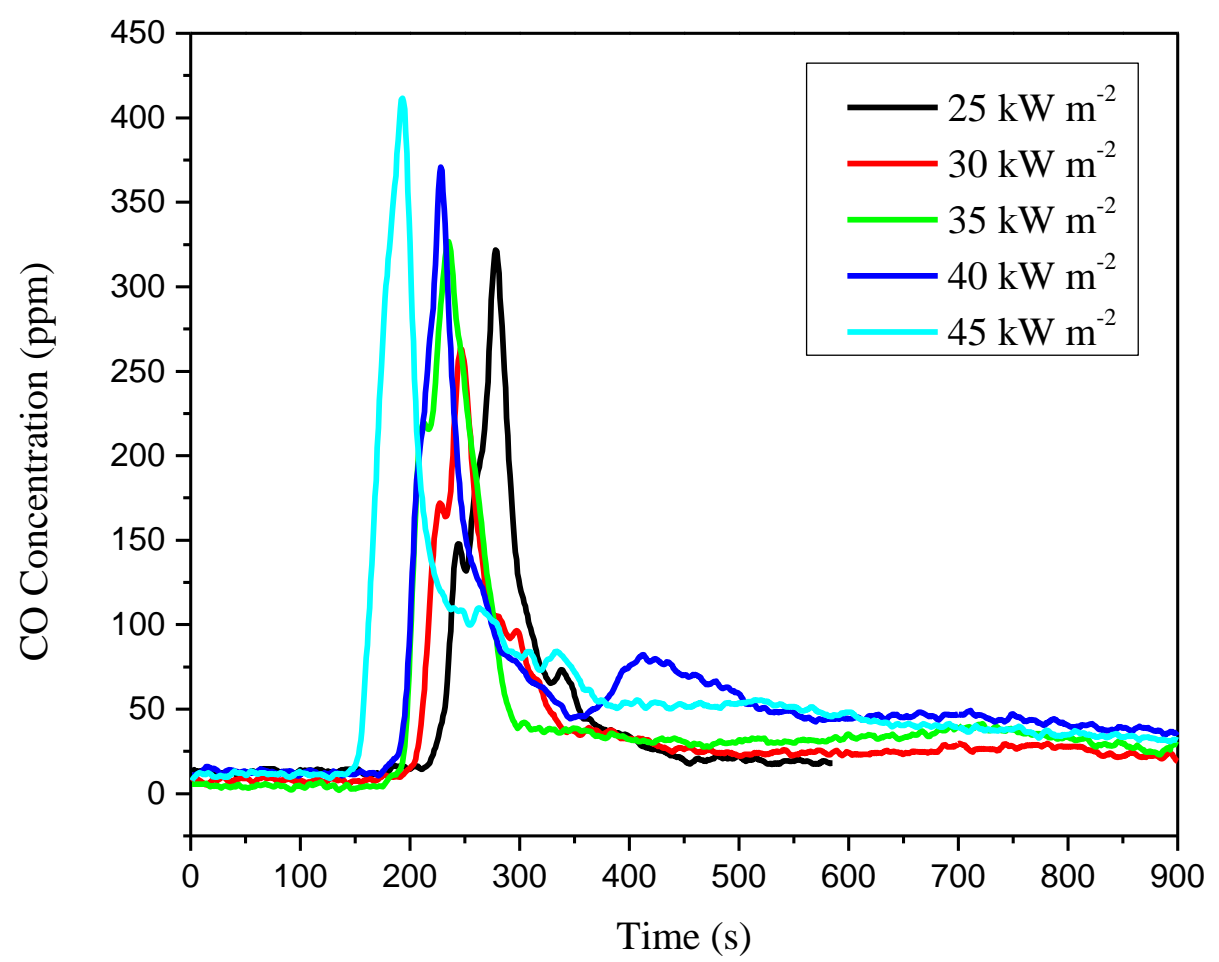

Figure 11. CO concentration versus time.

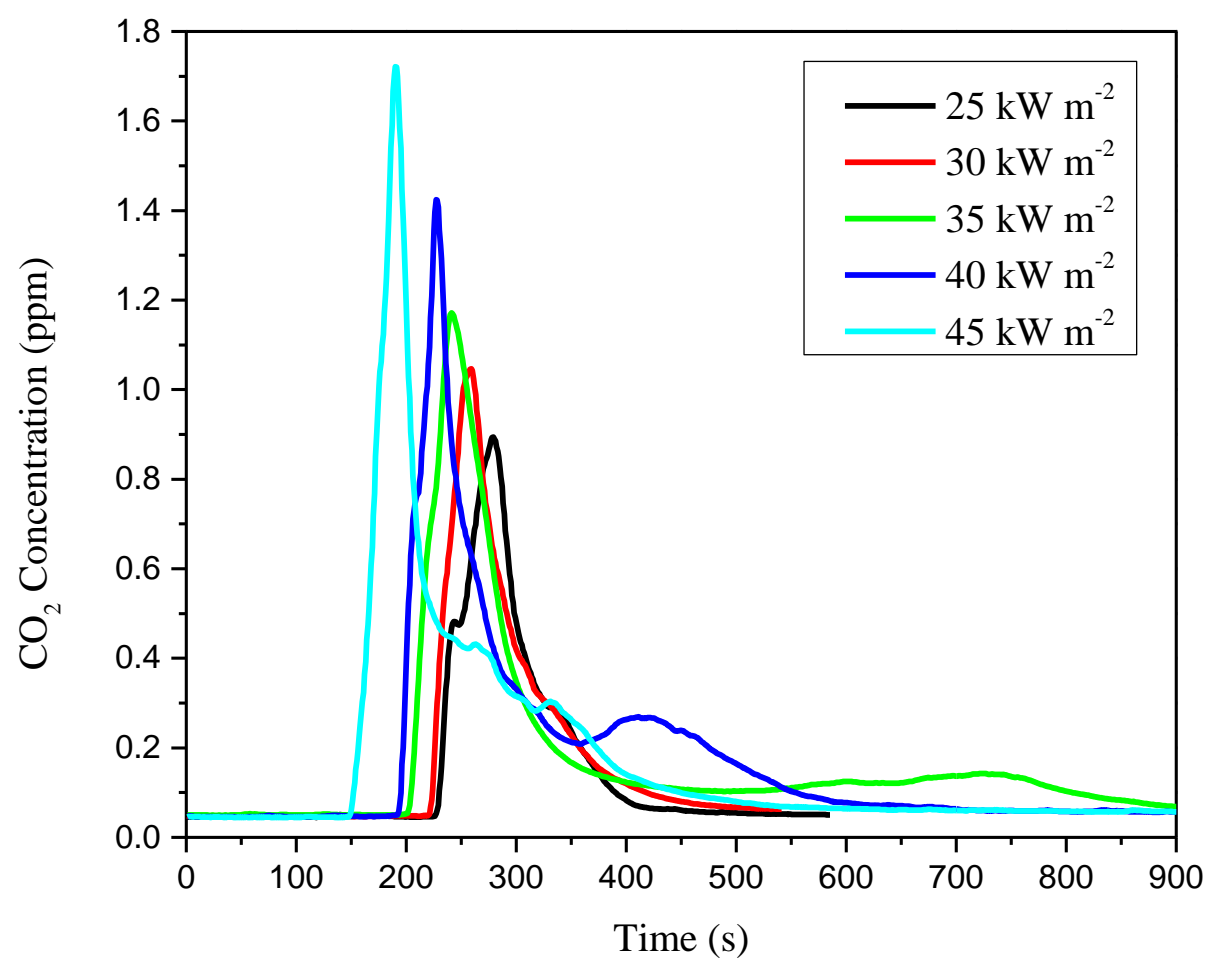

Figure 12. $\mathrm{CO}_{2}$ concentration versus time.

More detailed experimental and derived data can be found in Table 3. It is observed that the maximum of concentration of $\mathrm{CO}_{2}$ increases from $0.89 \%$ to $1.72 \%$ while the external heat flux varies from 25 to $45 \mathrm{~kW} \mathrm{~m}^{-2}$. However, the concentration maximum of $\mathrm{CO}$ in ppm is not simply increased. When the external heat flux decreases, the concentration of $\mathrm{CO}$ decreases as well, but in the test of 
$25 \mathrm{~kW} \mathrm{~m}^{-2}$ (321.8 ppm), the concentration reaches a large value compared with that of $30 \mathrm{~kW} \mathrm{~m}^{-2}$ (263.4 ppm). As the CIGS thin-film solar cells' special multi-layer structure, the stainless steel substrate on which the CIGS cells lie, and even the photovoltaic foils, brings difficulties for the under layers to contact air, especially when the external heat flux is not large enough to burn through the stainless steel substrate. The residue of the test of $25 \mathrm{~kW} \mathrm{~m}^{-2}$ found the stainless steel substrate with almost no damage, which signifies an incomplete combustion of the substrate. Thus, combustion may occur with more $\mathrm{CO}$ release.

Table 3. Results of gas concentration and toxicity index.

\begin{tabular}{|c|c|c|c|c|c|}
\hline $\begin{array}{l}\text { External Heat Flux } \\
\quad\left(\mathrm{kW} \mathrm{m}^{-2}\right)\end{array}$ & $\begin{array}{l}p k[C O] \\
(\mathrm{ppm})\end{array}$ & $\begin{array}{c}p k\left[\mathrm{CO}_{2}\right] \\
(\%)\end{array}$ & $\begin{array}{c}\text { FED } \\
(-)\end{array}$ & $\begin{array}{c}\text { FED }_{\text {cor }} \\
(-)\end{array}$ & $\begin{array}{c}L C_{50} \\
\left(\mathrm{~g} \mathrm{~m}^{-3}\right)\end{array}$ \\
\hline 25 & 321.8 & 0.89 & 0.064 & 0.123 & 24.25 \\
\hline 30 & 263.4 & 1.04 & 0.053 & 0.112 & 26.72 \\
\hline 35 & 326.6 & 1.17 & 0.065 & 0.131 & 22.92 \\
\hline 40 & 370.9 & 1.42 & 0.074 & 0.167 & 17.95 \\
\hline 45 & 411.5 & 1.72 & 0.082 & 0.190 & 15.82 \\
\hline
\end{tabular}

The peak fractional effective dose (FED) is denoted by Equation (10) referring to the N-GAS model, which means the sum of the fraction of the concentration and the lethal concentration for $50 \%$ of the population $\left(L C_{50}\right)$ for each gas over a 30 min exposure time, with a 14-day post-exposure period, predicts that the fire gas will be lethal to $50 \%$ of a laboratory rat population [48].

$$
F E D=\frac{m[C O]}{\left[\mathrm{CO}_{2}\right]-b}+\frac{21-\left[\mathrm{O}_{2}\right]}{21-L C_{50, \mathrm{O}_{2}}}+\frac{[\mathrm{HCN}]}{L C_{50, \mathrm{HCN}}}+\cdots
$$

Due to the fact that only concentrations of $\mathrm{CO}$ and $\mathrm{CO}_{2}$ are detected, FED is calculated from the peak concentration of $\mathrm{CO}$ and $\mathrm{CO}_{2}$ denoted by $[\mathrm{CO}]$ and $\left[\mathrm{CO}_{2}\right]$ and the $L C_{50}$ denoted by $L C_{\mathrm{CO}}$ and $\mathrm{LC}_{\mathrm{CO} 2}$ :

$$
F E D=\frac{[\mathrm{CO}]}{L C_{\mathrm{CO}}}+\frac{\left[\mathrm{CO}_{2}\right]}{\mathrm{LC}_{\mathrm{CO}_{2}}}
$$

The toxic potencies of $\mathrm{CO}_{2}$ are very large, and FED can be calculated only from the peak value of [CO], denoted by pk[CO], taking the toxic potency $L C_{50}$ of $C O$ as 5000 ppm [44]:

$$
F E D=\frac{p k[C O]}{5000}
$$

It was found from a developed database that $L C_{50}$ in actual fires would not deviate much from $L C_{50}$ determined by bench-scale tests. However, Han and Chow suggest that the calculation of FED and $L C_{50}$ in a cone calorimeter test is under well-ventilated conditions that may bring underestimation of the gas concentration [24]. They suggest an adjustment of gas concentration extracted from the burning facility with over-ventilated conditions, and this leads to a different result of FED and $L C_{50}$. FED calculated in this way is denoted here as $\mathrm{FED}_{\text {cor }}$.

It is assumed that all the toxic gases can be collected in a chamber volume $\left(V_{c}\right)$ of burning air, the gas concentration increasing to the peak value at the time of burning out [24]. The $L C_{50}$ (in ppmv or $\mathrm{g} \mathrm{m}^{-3}$ ) is calculated from the sample mass loss $\Delta m$ and $V_{c}$ :

$$
L C_{50}=\frac{\Delta m}{F E D_{c o r} \times V_{c}}
$$


In order to get the $\mathrm{FED}_{\mathrm{cor}}$, a transient concentration of $\mathrm{CO}$ as a volume ratio, $[\mathrm{CO}]_{t}$, is given by the ratio of the integrated volume $V_{C O}^{0 \rightarrow t}$ and $V_{c}$ :

$$
[C O]_{t}=\frac{V_{C O}^{0 \rightarrow t}}{V_{c}}=\frac{\int_{0}^{t}[C O]_{\text {Cone }} \dot{V}_{\text {Cone }} d t}{V_{c}}
$$

The results of $\mathrm{FED}_{\text {cor }}$ and $L C_{50}$ are shown in Table 3, with the volume $V_{c}$ setting to be $0.01 \mathrm{~m}^{3}$ like [25].

The data shown in Table 3 brings us to the following conclusions:

(1) Compared with values without the consideration of good ventilation, $\mathrm{FED}_{\text {cor }}$ deduced using Han and Chow's method is almost twice as high. $L C_{50}$ is $26.72 \mathrm{~g} \mathrm{~m}^{-3}$ at $30 \mathrm{~kW} \mathrm{~m}^{-2}$, and is higher than that in other conditions.

(2) Calculating FED is an intermediate step to deduce $L C_{50}$. A proper way to get $L C_{50}$ from cone calorimeter tests is relatively simple and easy to operate.

\section{Discussion}

Thermal properties and combustion behavior of CIGS thin-film solar modules was studied in detailed. CIGS thin-film solar cell technology is considered to be a promising substitute for fossil fuel because of its high efficiency and mass manufacture. Solar modules have been used as a part of exterior wall covering in personnel-intensive area. Under the premise of whole-module testing, a series of bench-scale tests on a cone calorimeter test bed were conducted. The results are compared with the glass covered polycrystalline silicon PV modules by Yang [22].

Taking MiaSolé as a sample, the same flexible cells are used for both glass and flexible modules [49]. However, the module structures are completely different. A glass module can be separated into five layers: top glass, encapsulant, cells, encapsulant and back glass. The main combustible component is encapsulant. As for a flexible module, the front and back barriers change from glass to polymer. These changes bring more combustible components.

In the incipient ignition stage, ignition behavior is different. In Yang's research, fire ignited from the edge of Si PV specimen. This fire behavior mainly results from the glass cover layer of module. As a non-combustible material, glass covering used in a PV module also has better fire-resistance performance. It is good at resistance to fire penetration and transfer of excessive heat. Under the glass cover, some combustible materials, like encapsulate (i.e., ethylene-vinyl acetate copolymer) are much easier to ignite at the specimen's verge. This is because encapsulate contacts with air. However, glass cover is not flexible enough. Our research considers a flexible CIGS PV module with ETFE cover. When the CIGS sample was exposed under radiation, the temperature of center was higher than the module margin. Because ETFE is combustible, ignition always begins at the center. The second difference is ignition time. Ignition time of a CIGS module is shorter than an Si PV module under the same conditions. The module with ETFE top layer is easier to ignite.

During the fire process, glass covers always broke into fragments. Those fragments are a potential danger for firefighters. This result would not happen with the ETFE cover layer. However, when ETFE burns, it releases hydrofluoric acid (HF). HF is extremely corrosive and toxic, therefore appropriate action must be taken when facing this condition [50]. As for different modules, the fire processes have similar single peak image of HRR. In order to evaluate fire hazard, some results can be found from Petrella's assessment. The THRs were in the range of 38-78 MJ m ${ }^{-2}$ for CIGS module and 38-57 MJ $\mathrm{m}^{-2}$ for Si module. This means these two modules both are at intermediate risk of heat combustion. However, for the index to evaluate the risk of flashover, the glass-cover Si module had lower risk than the ETFE-cover CIGS module. 


\section{Conclusions}

Research was carried out on the combustion behavior and fire hazard of CIGS thin-film solar modules. Cone calorimeter tests were conducted under five different external radiations varied from 25 to $45 \mathrm{~kW} \mathrm{~m}^{-2}$. Parameters were measured, such as surface temperature, ignition time, heat release rate, mass loss rate, $\mathrm{CO}$ concentration and $\mathrm{CO}_{2}$ concentration. SEM images of CIGS layers before and after burning test show that the CIGS cells structure is not changed. When the specimen was exposed to heat flux, a temperature gradient was observed. It shows the thermally thick property of the PV module. The ETFE cover layer is easily ignited when heat flux is greater than $25 \mathrm{~kW} \mathrm{~m}^{-2}$, which is representative of a real fire. ETFE released hydrofluoric acid during its burning process. This is a great danger for fire fighters and needs attention. The gasification heat of the module is $12.52 \mathrm{~kJ} \mathrm{~g}^{-1}$, and the net flame heat flux is $4.91 \mathrm{~kW} \mathrm{~m}^{-2}$. These two parameters are required in fire modeling.

In order to discuss the hazardous nature of fire smoke toxicity, Petrella's evaluation system was introduced. In this research, the heat contribution risk was intermediate low with a THR range of 38-78 $\mathrm{MJ} \mathrm{m}^{-2}$. The flashover risk was high when external heat flux was greater than $35 \mathrm{~kW} \mathrm{~m}^{-2}$. Correction calculation of FED and $L C_{50}$ of under well-ventilation condition was used. $L C_{50}$ was $26.72 \mathrm{~g} \mathrm{~m}^{-3}$ at $30 \mathrm{~kW} \mathrm{~m}^{-2}$, and was higher than other conditions.

With the aim of reducing the fire risk of the whole module, the barrier and encapsulant layers need more research. The flame retardancy of the front barrier determines the difficulty of ignition. Additionally, the flex backsheet and encapsulant are all combustible components. The total heat release is mainly determined by these three layers.

Different materials of cover layer or other structure in the product could lead to different hazard levels. Most studies in the thin-film solar cells area focus on electric parameters such as light transmittance, efficiency etc. Only few researches consider the PV module as a whole to study fire behavior and fire hazards. These experimental data provide basic parameters to assess PV fire. For deeper research, full-scale tests and fire propagation tests could be considered in future studies.

Author Contributions: L.Y., Y.J. and R.Q. conceived and designed the experiments; L.Y. performed the experiments; L.Y. analyzed the data; Y.J. and R.Q. contributed materials; L.Y., Y.J. and R.Q. wrote the paper.

Funding: This research was funded by the National Natural Science Foundation of China (Grand No. 51576183), and the Fundamental Research Funds for the Central Universities (Grand Nos.WK2320000033 and WK2320000035).

Conflicts of Interest: The authors declare no conflicts of interest.

\section{References}

1. Płaczek-Popko, E. Top PV market solar cells 2016. Opto-Electron. Rev. 2017, 25, 55-64. [CrossRef]

2. Lee, T.D.; Ebong, A.U. A review of thin film solar cell technologies and challenges. Renew. Sustain. Energy Rev. 2017, 70, 1286-1297. [CrossRef]

3. Chopra, K.L.; Paulson, P.D.; Dutta, V. Thin-film solar cells: An overview. Prog. Photovolt. Res. Appl. 2004, 12, 69-92. [CrossRef]

4. Ramanathan, K.; Contreras, M.A.; Perkins, C.L.; Asher, S.; Hasoon, F.S.; Keane, J.; Young, D.; Romero, M.; Metzger, W.; Noufi, R. Properties of $19.2 \%$ efficiency $\mathrm{ZnO} / \mathrm{CdS} / \mathrm{CuInGaSe}_{2}$ thin-film solar cells. Prog. Photovolt. Res. Appl. 2003, 11, 225-230. [CrossRef]

5. Solar Frontier Hits 22.3\% on CIGS Cell. Available online: https:/ /www.pv-magazine.com/2015/12/08/ solar-frontier-hits-22-3-on-cigs-cell_100022342/ (accessed on 20 September 2016).

6. First Solar Hits Record 22.1\% Conversion Efficiency for CdTe Solar Cell. Available online: https: / / www.greentechmedia.com/articles / read/First-Solar-Hits-Record-22.1-Conversion-EfficiencyFor-CdTe-Solar-Cell (accessed on 08 November 2016).

7. Sai, H.; Matsui, T.; Koida, T.; Matsubara, K.; Kondo, M.; Kondo, M.; Sugiyama, S.; Katayama, H.; Takeuchi, Y.; Yoshida, I. Triple-junction thin-film silicon solar cell fabricated on periodically textured substrate with a stabilized efficiency of 13.6\%. Appl. Phys. Lett. 2015, 106, 213902.

8. Shehata, N.; Clavel, M.; Meehan, K.; Samir, E.; Gaballah, S.; Salah, M. Enhanced Erbium-Doped Ceria Nanostructure Coating to Improve Solar Cell Performance. Materials 2015, 8, 7663-7672. [CrossRef] [PubMed] 
9. Jeng, M.J.; Chen, Z.Y.; Xiao, Y.L.; Chang, L.B.; Ao, J.; Sun, Y.; Popko, E.; Jacak, W.; Chow, L. Improving Efficiency of Multicrystalline Silicon and CIGS Solar Cells by Incorporating Metal Nanoparticles. Materials 2015, 8, 6761-6771. [CrossRef] [PubMed]

10. Passoni, L.; Ghods, F.; Docampo, P.; Abrusci, A.; Martí-Rujas, J.; Ghidelli, M.; Divitini, G.; Ducati, C.; Binda, M.; Guarnera, S.; et al. Hyperbranched Quasi-1D Nanostructures for Solid-State Dye-Sensitized Solar Cells. ACS Nano 2013, 7, 10023-10031. [CrossRef] [PubMed]

11. Gondoni, P.; Ghidelli, M.; Di Fonzo, F.; Li Bassi, A.; Casari, C.S. Fabrication of nano-engineered transparent conducting oxides by pulsed laser deposition. J. Vis. Exp. JoVE 2013, 72, e50297. [CrossRef] [PubMed]

12. Deelen, J.V.; Omar, A.; Barink, M. Optical Design of Textured Thin-Film CIGS Solar Cells with Nearly-Invisible Nanowire Assisted Front Contacts. Materials 2017, 10, 392. [CrossRef] [PubMed]

13. Hu, J.; Chen, W.; Liu, Y.; Zhao, B.; Yang, D.; Ge, B. Two-layer ETFE cushions integrated flexible photovoltaics: Prototype development and thermal performance assessment. Energy Build. 2017, 141, 238-246. [CrossRef]

14. Maurus, H.; Schmid, M.; Blersch, B.; Lechner, P.; Schade, H. PV for buildings. Refocus 2004, 5, $22-27$. [CrossRef]

15. Wohlgemuth, J.H.; Kurtz, S.R. How Can We Make PV Modules Safer? In Proceedings of the 2012 38th IEEE Photovoltaic Specialists Conference, Austin, TX, USA, 3-8 June 2012; Institute of Electrical and Electronics Engineers (IEEE): Piscataway, NJ, USA, 2012.

16. International Electrotechnical Commission. Photovoltaic (PV) Module Safety Qualification-Part 2: Requirements for Testing; IEC 61730-2:2004; International Electrotechnical Commission: Geneva, Switzerland, 2004.

17. Underwriters Laboratories Inc. Flat-Plate Photovoltaic Modules and Panels; UL 1703; Underwriters Laboratories Inc.: Northbook, IL, USA, 2004.

18. Underwriters Laboratories Inc. Fire Test of Roof Deck Constructions; UL 1256; Underwriters Laboratories Inc.: Northbrook, IL, USA, 2002.

19. Guerin, T.F. Evaluating expected and comparing with observed risks on a large-scale solar photovoltaic construction project: A case for reducing the regulatory burden. Renew. Sustain. Energy Rev. 2017, 74, 333-348. [CrossRef]

20. Casey, C.; Grant, P.E. Fire Fighter Safety and Emergency Response for Solar Power Systems; The Fire Protection Research Foundation: Quincy, MA, USA, 2010.

21. Fthenakis, V.M.; Fuhrmann, M.; Heiser, J.; Lanzirotti, A.; Fitts, J.; Wang, W. Emissions and encapsulation of cadmium in CdTe PV modules during fires. Prog. Photovolt. Res. Appl. 2005, 13, 713-723. [CrossRef]

22. Yang, H.-Y.; Zhou, X.-D.; Yang, L.-Z.; Zhang, T.-L. Experimental Studies on the Flammability and Fire Hazards of Photovoltaic Modules. Materials 2015, 8, 4210-4225. [CrossRef] [PubMed]

23. Fu, Y.; Lu, S.; Li, K.; Liu, C.; Cheng, X.; Zhang, H. An experimental study on burning behaviors of 18650 lithium ion batteries using a cone calorimeter. J. Power Sources 2015, 273, 216-222. [CrossRef]

24. Han, S.S.; Chow, W.K. Calculating FED and LC50 for testing toxicity of materials in bench-scale tests with a cone calorimeter. Polym. Test. 2005, 24, 920-924. [CrossRef]

25. MiaSolé FLEX SERIES-01N. Available online: http://miasole.com/uploads/media/MiaSole_datasheet_ FlexSeries_01N_CN.pdf (accessed on 20 September 2016).

26. ISO 5660-1. Reaction-to-Fire Tests-Heat Release, Smoke Production and Mass Loss Rate-Part 1: Heat Release Rate (Cone Calorimeter Method) and Smoke Production Rate (Dynamic Measurement); ISO: Geneva, Switzerland, 2015.

27. Fateh, T.; Richard, F.; Batiot, B.; Rogaume, T.; Luche, J.; Zaida, J. Characterization of the burning behavior and gaseous emissions of pine needles in a cone calorimeter-FTIR apparatus. Fire Saf. J. 2016, 82, 91-100. [CrossRef]

28. Babrauskas, V. Speciman heat fluxes for bench-scale heat release rate testing. Fire Mater. 1995, 19, $243-252$. [CrossRef]

29. Sibiński, M.; Znajdek, K. Innovative Elastic Thin-Film Solar Cell Structures; INTECH Open Access Publisher: New York, NY, USA, 2011.

30. Ullal, H.S.; Von Roedern, B. Thin film CIGS and CdTe photovoltaic technologies: Commercialization, critical issues, and applications. In Proceedings of the 22nd European Photovoltaic Solar Energy Conference, Milan, Italy, 3-7 September 2007.

31. Incropera, F.P.; Bergman, T.L.; Lavine, A.S.; DeWitt, D.P. Fundamentals of Heat andMass Transfer, 6th ed.; John Wiley \& Sons: New York, NY, USA, 2007; pp. 260-261. 
32. Fateh, T.; Rogaume, T.; Luche, J.; Richard, F.; Jabouille, F. Characterization of the thermal decomposition of two kinds of plywood with a cone calorimeter-FTIR apparatus. J. Anal. Appl. Pyrolysis 2014, 107, 87-100. [CrossRef]

33. Dao, D.Q.; Luche, J.; Richard, F.; Rogaume, T.; Bourhy-Weber, C.; Ruban, S. Determination of characteristic parameters for the thermal decomposition of epoxy resin/carbon fibre composites in cone calorimeter. Int. J. Hydrog. Energy 2013, 38, 8167-8178.

34. Spearpoint, M.J.; James, G.Q. Predicting the piloted ignition of wood in thecone calorimeter using an integral model. Fire Saf. J. 2001, 36, 391-415. [CrossRef]

35. Wichman, I.S.; Areya, A. A simplified model for the pyrolysis of charring materials. Combust. Flame 1987, 68, 231-247. [CrossRef]

36. Luche, J.; Mathis, E.; Rogaume, T.; Richard, F.; Guillaume, E. High-densitypolyethylene thermal degradation and gaseous compound evolution in a conecalorimeter. Fire Saf. J. 2012, 54, 24-35. [CrossRef]

37. Spearpoint, M.J.; Quintiere, J.G. Predicting the piloted ignition of wood in the cone calorimeter using an integral model-Effect of species, grain orientation and heat flux. Fire Saf. J. 2001, 36, 391-415. [CrossRef]

38. Mark, J.E. (Ed.) Physical Properties of Polymers Handbook; Springer: New York, NY, USA, 2007.

39. Tewarson, A. SFPE Handbook of Fire Protection Engineering; NFPA: New York, NY, USA, 2002.

40. Kotresh, T.M.; Indushekar, R.; Subbulakshmi, M.S.; Vijayalakshmi, S.N.; Krishna Prasad, A.S.; Padaki, V.C.; Agrawal, A.K. Effect of heat flux on the burning behaviour of foam and foam/Nomex III fabric combination in the cone calorimeter. Polym. Test. 2006, 25, 744-757. [CrossRef]

41. Delichatsios, M.A.; Panagiotou, T.; Kiley, F. The use of time to ignition data for characterizing the thermal inertia and the minimum (critical) heat flux for ignition or pyrolysis. Combust. Flame 1991, 84, 323-332. [CrossRef]

42. Eshetu, G.G.; Grugeon, S.; Laruelle, S.; Boyanov, S.; Lecocq, A.; Bertrand, J.P.; Marlair, G. In-depth safety-focused analysis of solvents used in electrolytes for large scale lithium ion batteries. Phys. Chem. Chem. Phys. PCCP 2013, 15, 9145-9155. [CrossRef] [PubMed]

43. Delichatsios, M.A.; Ris, L.D. An Analytical Model for the Pyrolysis of Charring Materials; Factory Mutual Technical Report; Factory Mutual Research: Washington, DC, USA, 1983.

44. Chow, W.K.; Han, S.S. Studies on fire behaviour of video compact disc (VCD) materials with a cone calorimeter. Polym. Test. 2004, 23, 685-694. [CrossRef]

45. Xu, Q.; Chen, L.; Harries, K.A.; Zhang, F.; Liu, Q.; Feng, J. Combustion and charring properties of five common constructional wood species from cone calorimeter tests. Constr. Build. Mater. 2015, 96, 416-427. [CrossRef]

46. Rhodes, B.T.; Quintiere, J.G. Burning rate and flame heat flux for PMMA in a cone calorimeter. Fire Saf. J. 1996, 26, 221-240. [CrossRef]

47. Hopkins, D.; Quintiere, J.G. Material fire properties and predictions for thermoplastics. Fire Saf. J. 1996, 26, 241-268. [CrossRef]

48. International Organization for Standardization. Determination of the Lethal Toxic Potency of Fire Effluents, 1st ed.; International Organization for Standardization: Geneva, Switzerland, 1996.

49. Bayman, A. MiaSolé Flexible Productand Manufacturing. In Proceedings of the IW-CIGSTech, Munich, German, 23 June 2016.

50. ETFE. Available online: https://en.wikipedia.org/wiki/ETFE (accessed on 3 August 2018).

(C) 2018 by the authors. Licensee MDPI, Basel, Switzerland. This article is an open access article distributed under the terms and conditions of the Creative Commons Attribution (CC BY) license (http://creativecommons.org/licenses/by/4.0/). 